\title{
Strategi Rebalancing Amerika Serikat di Kawasan Asia-Pasifik
}

\section{Vanilla Planifolia}

Master Program in International Relations Department, Faculty of Social and Political Science, Universitas Indonesia, Kampus Baru UI Depok, Jawa Barat 16424, Indonesia

Email: vanilla.planifolia@ui.ac.id

Submitted: 21 Juli 2017, Accepted: 16 September 2017

\begin{abstract}
This paper will discuss why the United States changed its foreign policy from the Middle East to Asia-Pacific region. The dynamic of the region shows that China plays an important role along with its national capability improvement. The increase in China's national capability is seen as a challenge to national interests, as well as security for the United States alliance states in the Asia-Pacific region. Using an analytical framework based on the Balance of Threat theory, the author concludes that there is a strong relation between China's national capability improvements with the implementation of US rebalancing strategy to the Asia-Pacific region.

Keywords: Rebalancing strategy, alliance, balance of threat, security, Asia-Pacific region
\end{abstract}

\begin{abstract}
Abstrak
Tulisan ini mencoba menganalisa alasan Amerika Serikat mengubah fokus kebijakan luar negerinya dari Kawasan Timur Tengah ke Kawasan Asia-Pasifik. Dinamika kawasan yang terjadi, China memegang peran penting seiring dengan peningkatan kapabilitas nasionalnya. Peningkatan kapabilitas nasional China tersebut dilihat sebagai tantangan bagi kepentingan nasional, sekaligus keamanan bagi negara aliansi Amerika Serikat di Kawasan Asia-Pasifik. Dengan menggunakan kerangka analisa berdasarkan teori Balance of Threat, penulis menyimpulkan bahwa terdapat keterkaitan yang sangat kuat antara peningkatan kapabilitas nasional China dengan penerapan strategi rebalancing Amerika Serikat ke Kawasan Asia-Pasifik.

Kata Kunci: Strategi rebalancing, aliansi, perimbangan ancaman, keamanan, Kawasan Asia-Pasifik
\end{abstract}

\section{PENDAHULUAN}

"... Accordingly, while the U.S. military will continue to contribute to security globally, we will of necessity rebalance toward the Asia-Pacific region. Our relationship with Asian allies and key partners are critical to the future stability and growth of the region (Department of Defense of the United States of America, 2012)."

Ketika kepemimpinan Presiden Bush berganti ke Barack Obama pada tahun 2009, Amerika Serikat (AS) mulai mengubah fokus kebijakannya. Secara resmi AS menerapkan kebijakan rebalancing yang difokuskan ke Kawasan Asia-Pasifik, sehingga fokus kebijakan luar negeri AS tidak lagi ke Kawasan Timur Tengah melainkan Kawasan Asia. Hal tersebut diawali dengan penarikan pasukan AS dari Irak. Penarikan pasukan dari Kawasan
Timur Tengah memperkuat indikasi perubahan strategi dalam kebijakan militer AS ke Kawasan Asia-Pasifik. Penarikan pasukan tersebut mengikuti penetapan proporsi pasukan 60:40. Artinya, sebanyak 60\% pasukan AS yang dulunya berada di Timur Tengah ditempatkan di bawah komando the United States Pacific Command (USPACOM), sedangkan 40\% lainnya disebar ke komando kawasan yang lain (The White House - Office of the Press Secretary, 2011: 2).

Perubahan fokus dilakukan dengan pendekatan kepada negara aliansinya, melalui kunjungan kenegaraan maupun dialog kerja sama di berbagai bidang terutama keamanan antar pemerintah. Kawasan Asia-Pasifik menjadi fokus dari perubahan kebijakan luar negeri AS karena dianggap 
mengalami perkembangan yang signifikan, terutama dalam bidang ekonomi dan militer. Perkembangan tersebut memunculkan kemungkinan akan dampak politik dan keamanan, baik kemungkinan konflik ataupun kerja sama antarnegara di kawasan, mengingat banyaknya peluang dan tantangan di era globalisasi.

"Here, we see the future. As the world's fastest-growing region -and home to more than half the global economythe Asia-Pacific is critical to achieving my highest priority: creating jobs and opportunity for the American people. With most of the world's nuclear powers and some half of humanity, Asia will largely define whether the century ahead will be marked by conflict or cooperation, needless suffering or human progress (Department of Defense of United States of America, 2012: 4)."

Pidato Presiden Obama di atas menunjukkan bagaimana Kawasan Asia-Pasifik dipandang sebagai pusat aktivitas dunia internasional di abad ke-21. Aktivitas yang dialami oleh negara-negara Asia-Pasifik tentunya akan menimbulkan konstelasi. Konstelasi di sini dalam artian banyaknya kemungkinan yang terjadi. Dengan kompleksitas yang ada, kemungkinan terjadinya konflik atau kerja sama akan semakin besar. Hal tersebut menimbulkan interaksi yang tidak hanya melibatkan hubungan antarnegara, tetapi juga interaksi antar-masyarakat internasional.

Berdasarkan pernyataan resmi AS, 'Pivot to Asia' merupakan sebuah ungkapan atas strategi yang difokuskan ke Kawasan Asia-Pasifik. Strategi tersebut berupa konsentrasi arah kebijakan luar negeri yang merupakan kelanjutan dari kepentingan nasional AS (Reis, 2014). Upaya yang diterapkan oleh AS adalah sebagai bentuk prioritas politik luar negerinya ke Kawasan Asia-Pasifik. Strategi ini memfokuskan pada beberapa bagian, di antaranya adalah pengembangan kerja sama ekonomi, penguatan terhadap negara aliansi, jaminan keamanan bersama melalui institusi regional untuk membantu menangani sengketa terkait batas wilayah secara damai.

Pada pemerintahan Bush, AS telah melakukan penguatan aliansi di Kawasan Asia, kemudian lebih diperkuat lagi oleh pemerintahan Obama dengan menempatkan pasukan dan peralatan militer ke Australia dan Singapura (CRS, 2012). Dalam tulisan yang dilakukan oleh Congressional Research Service (CRS), tujuan utama dari 'Pivot to Asia' ini adalah untuk memberikan pengaruh lebih besar terhadap perkembangan di Kawasan Asia-Pasifik, di antaranya dalam hal ekonomi, sosial, keamanan termasuk militer. Pengaruh tersebut termasuk penguatan hubungan dengan negara di Kawasan Asia-Pasifik, terutama negara aliansi. Pada pemerintahan Obama, hal yang paling terlihat adalah penempatan pasukan ke Australia dan Singapura yang menjadi negara aliansinya.

Pivot to Asia atau yang secara resmi disebut dengan strategi rebalancing bersifat luas, tidak terbatas pada elemen pertahanan militer tetapi juga ekonomi, sosial, politik, serta diplomasi, yang diyakini beberapa pihak akan menimbulkan resiko terhadap hubungan negara-negara di AsiaPasifik, terutama terkait dengan munculnya persepsi ancaman dari negara lain. Beberapa pro dan kontra mengikuti penetapan strategi AS ke Kawasan Asia-Pasifik ini, terutama munculnya berbagai spekulasi mengenai hubungan bilateral antara AS dengan China. Dalam beberapa dokumen dan hasil penelitian, China secara khusus disebutkan sebagai tantangan bagi keberhasilan strategi yang sedang dijalankan. Beberapa pihak menggarisbawahi bahwa kehadiran AS ke Kawasan Asia-Pasifik ini dipicu oleh peningkatan kapabilitas China yang menjadi kekuatan baru di kawasan baik di bidang ekonomi, diplomasi, maupun militer.

Secara tidak langsung, dapat dikatakan bahwa AS berhasil menguasai Kawasan Asia-Pasifik dalam Perang Dunia II. Berhasilnya AS di kawasan ini ditunjukkan dengan terbangunnya aliansi dengan Jepang, Korea Selatan, Thailand, dan Singapura, yang masih berlanjut hingga saat ini (The White House-Office of the Press Secretary, 2011: 2). Dengan menguatnya China yang bukanlah negara aliansi serta memiliki potensi untuk mendominasi Kawasan Asia-Pasifik, AS merasa terancam atas kredibilitas pengaruhnya di regional. Ancaman tersebut tidak hanya berdampak langsung bagi AS, tetapi juga negara aliansinya yang secara geografis berada dekat dengan China, sehingga merasa perlu melakukan penguatan kembali dengan upaya menekan perkembangan China.

Tulisan ini akan memfokuskan pembahasan pada kembalinya kehadiran AS di Asia-Pasifik sebagai upaya rebalancing terhadap China yang dianggap sebagai ancaman 
baru di kawasan. Pembahasan tersebut akan menunjukkan lebih dalam mengenai kebijakan yang dikeluarkan pemerintah AS terutama dalam bidang strategi militer yang berusaha mengimbangi kekuatan China dengan kemampuan yang sudah mencapai A2/AD. Selanjutnya, tulisan ini akan menjelaskan kaitannya dengan peningkatan kapabilitas militer China, terutama upaya penguatan aliansi dan militer AS ke Kawasan Asia-Pasifik dengan mengonsentrasikan kapabilitas Anti-Access/Area Denial.

\section{KERANGKA PEMIKIRAN}

\section{ASPEK PERHITUNGAN TINGKAT ANCAMAN}

Kerangka analisis yang digunakan untuk menjawab pertanyaan dalam tulisan ini adalah kerangka teoritis yang dicetuskan oleh Stephen M. Walt. Teori Balance of Threat menekankan pada upaya perimbangan untuk mengatasi ancaman yang ada, bukan mengimbangi kekuatan lawan. Untuk melihat tingkatan ancaman dari pihak lain, Balance of Threat memiliki daya ukur untuk melihat seberapa jauh kekuatan lawan dan kekuatan nasional untuk melakukan perimbangan ancaman. Ada empat hal yang bisa menjadi daya ukur kekuatan negara untuk memberikan dampak ancaman, yaitu total kekuatan negara (aggregate power), kedekatan geografis (geographic proximity), kapabilitas militer yang bersifat ofensif (offensive power), dan mampu menunjukkan sifat yang agresif terhadap lawan (perceived aggressiveness).

Balance of Threat dapat digunakan untuk melihat bagaimana suatu negara dianggap sebagai ancaman. Aggregate power merupakan kekuatan relatif yang dimiliki oleh suatu negara, seperti kemampuan industri, kapasitas militer, kekuatan ekonomi yang dilihat dari total GDP, dan kemajuan teknologi (Walt, 1987: 17-20). Dapat dikatakan bahwa aggregate power ini merupakan total sumber daya yang dimiliki negara. Kekuatan militer suatu negara akan dipengaruhi oleh kekayaan sumber daya alam, kemajuan teknologi, jumlah populasi, dan pengembangan industri. Dengan begitu, kekuatan militer akan dapat tertopang dan dapat terus dikembangkan. Peningkatan kapabilitas nasional suatu negara, terlebih lagi kapabilitas militer akan menimbulkan ancaman bagi negara lain, terutama negara yang tidak memiliki kemampuan yang setara.

Geographic Proximity merupakan ancaman yang ditimbulkan karena kedekatan geografis. Apabila semakin dekat jarak antar negara, maka semakin besar potensi ancaman yang ditimbulkan (Walt, 1987: 23). Kemampuan negara dalam memproyeksikan kekuatan dipengaruhi oleh jarak, terlebih lagi apabila berbatasan secara langsung. Pemikiran suatu negara akan mempertimbangkan ancaman terdekat daripada ancaman yang ditimbukan oleh negara yang berada lebih jauh. Jauh dekatnya jarak akan berpengaruh pada sifat agresif negara, sehingga membutuhkan kapabilitas nasional yang lebih besar apabila ingin menjangkau letak negara yang jauh (Dwivedi, 2012: 230231).

Offensive Power merupakan kapabilitas militer suatu negara yang bersifat menyerang. Kekuatan militer yang berkemampuan menyerang akan memberikan ancaman bagi negara lain (Walt, 1987: 24). Terlebih lagi apabila negara tersebut saling berdekatan, sehingga kemungkinan untuk mengancam kedaulatan negara lain akan semakin besar. Dengan kapabilitas militer suatu negara yang semakin besar, maka dapat memicu terjadinya aliansi dengan negara lain terutama dengan negara yang berkapabilitas militer lebih lemah. Offensive power dapat dibangun apabila negara tersebut memiliki tenaga manusia yang cukup, kemampuan mengembangkan nuklir, daya jangkau pertahanan yang melebihi batas negaranya, serta mengembangkan teknologi militer yang ditopang dengan kekuatan ekonomi (Walt, 1987: 24).

Aggressive Intention adalah pengaruh yang ditimbulkan oleh suatu negara untuk memprovokasi negara lain yang sama-sama merasa terancam oleh kekuatan musuh (Walt, 1987: 25). Provokasi tersebut ditujukan untuk perimbangan kekuatan dengan melakukan aliansi. Selain itu, kemampuan suatu negara dalam menerapkan kebijakan atau strategi yang mengarah ke negara lain juga menjadi salah satu elemen dari aggressive intention.

Keempat aspek diatas merupakan cara yang dikemukakan oleh Stephen Walt untuk melihat ancaman yang dimiliki negara lain. Negara memutuskan melakukan upaya aliansi dalam merespon ancaman dapat dilakukan dengan 2 (dua) strategi utama, yaitu balancing dan bandwagoning. Kedua strategi tersebut dapat dilakukan negara apabila mendapatkan ancaman eksternal. Dalam balancing, negara melakukan aliansi dengan pihak lain untuk menghadapi 
negara yang memberikan ancaman. Sedangkan bandwagoning, negara melakukan pendekatan dengan negara yang memberikan ancaman.

\section{PEMBAHASAN}

PEMETAAN KAPABILITAS CHINA DI KAWASAN ASIA-PASIFIK

Tahun 2004, China di bawah kepemimpinan Hu Jintao melaksanakan kebijakan China's Peaceful Development. Pada dasarnya, kebijakan tersebut telah diberlakukan sejak China melakukan revolusi pasca digantikannya Mao oleh Deng Xiao Ping. Kemajuan yang dibuat China serta kebijakan yang dikeluarkan oleh China pada saat itu menimbulkan respon yang beragam, hingga muncul sebutan 'China Rise' untuk peningkatan yang dicapai (Bijan, 2005). Kembali pada tahun 2004, apabila mengaitkan antara 'China Rise' dengan kebijakan luar negeri China yang sebenarnya adalah China's Peaceful Development. Presiden Hu Jintao kembali menegaskan bahwa kebijakan tersebut diberlakukan seiring dengan meningkatnya kemampuan China mulai dari politik, ekonomi, dan militer. Kebijakan tersebut ditujukan sebagai bukti kepada negara lain bahwa peningkatan China tidak akan mengancam ketenangan dan perdamaian terutama di Kawasan Asia-Pasifik (Information Office of the State Council of The People's Republic of China, 2011).

Berdasarkan informasi Office of the State Council of the People's Republic of China, inti dari China Peaceful Development secara umum adalah mengembangkan kemampuan nasional sehingga dapat berkontribusi dalam menjaga perdamaian dunia. Kemampuan China dicapai dengan melakukan reformasi sekaligus berinovasi mengikuti dinamika internasional terutama di era globalisasi (Information Office of the State Council of The People's Republic of China, 2011). Hingga saat ini, China tetap mempertahankan kebijakan reformasi yang terbukti menjadikan China sebagai regional power di Kawasan AsiaPasifik. Tahun 2009, pertumbuhan ekonomi China tidak kurang dari dua digit angka. Dengan jumlah penduduk yang mencapai dua miliar lebih menjadikan China sebagai pasar sekaligus produsen utama industri manufaktur. Selain penduduk, taraf hidup masyarakat China yang mayoritas kelas menengah menjadikan tingkat upah bersaing dan cenderung murah (Kementrian Luar Negeri
Indonesia, 2014). Sehingga menjadikan China sebagai negara tujuan investor di atas AS.

Secara garis besar, pencapaian China yang terjadi sejak 2010 adalah peningkatan perekonomian hingga US $\$ 5,88$ Triliun. Angka tersebut naik 16 kali dibandingkan pada tahun 1978, tahun dimulainya revolusi China di bawah kepemimpinan Deng Xiaoping. Ketika itu, China hanya mencapai $1,8 \%$ dari total pertumbuhan dunia, namun ketika tahun 2010 dapat mencapai 9,3\% dari total dunia. Kemudian dalam hal keamanan dan perkembangan militer, China merupakan negara yang memiliki senjata nuklir. Namun, China merupakan negara satu-satunya yang menyatakan tidak akan menggunakan senjata nuklir terlebih dahulu, mengancam negara lain yang tidak memiliki persenjataan nuklir atau di area bebas nuklir (Information Office of the State Council of The People's Republic of China, 2011).

Kawasan Asia-Pasifik adalah kawasan yang memiliki nilai penting dalam kegiatan dunia, melihat lokasi geografis dapat mempengaruhi kebijakan strategi dan kekuatan suatu negara yang ingin mencapai kepentingan nasionalnya. Kawasan Asia-Pasifik dipandang sebagai kawasan yang paling cocok untuk memahami pentingnya peran dalam membangun interaksi yang sifatnya multilateral. Salah satu negara yang difokuskan dalam tulisan ini, yaitu AS melihat bahwa kawasan ini sangat berpengaruh terhadap keamanan wilayahnya, karena Asia-Pasifik berbatasan langsung dengan Pantai Timur Amerika Serikat.

AS sendiri mengartikan Asia-Pasifik adalah kawasan yang terbentang dari Pasifik Barat dan Asia Timur termasuk kawasan Samudra Hindi dan Asia Selatan (Department of Defense of United States of America, 2012: 2). Sehingga, berdasarkan Amerika Serikat, Kawasan Asia-Pasifik terbentang mulai dari India berlajut ke Kawasan Asia Tenggara dan Mikronesia, kemudian ke utara yaitu Kawasan Asia Timur. Berikut gambaran jelas Kawasan AsiaPasifik berdasarkan United States Pacific Command (USPACOM). ${ }^{1}$

Akhir tahun 2011, Pemerintahan AS masa Presiden Barack Obama menandatangani keputusan Fiscal Year 2012 mengenai rencana postur pertahanan dan penempatan pasukan di bawah USPACOM. Sebelumnya, kebijakan Amerika terfokus pada war on terror pasca tragedi 9/11. 
Upaya memerangi terorisme terkonsentrasi di Kawasan Timur Tengah, terutama Irak dan Afganistan, karena dianggap menjadi markas jaringan teroris dunia al-Qaeda. Setelah persetujuan penetapan fiscal year, awal tahun 2012 pemerintahan Barack Obama mengeluarkan kebijakan terkait pertahanan AS. Kebijakan tersebut seperti yang terdapat dalam dokumen Sustaining U.S. Global Leadership: Priorities for 21st Century Defense. Timur Tengah yang dulunya menjadi fokus kebijakan luar negeri AS, pasca tahun 2011 mulai berubah fokus ke Kawasan Asia-Pasifik.

Gambar 1. Kawasan Asia-Pasifik

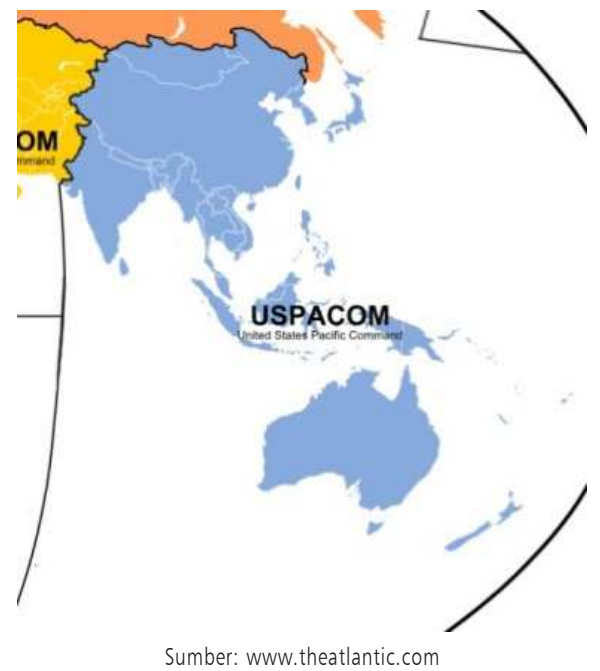

Perubahan mengarah pada peningkatan dan pengembangan peran AS di Kawasan Asia-Pasifik, terutama bagian selatan. Pada awalnya, Amerika Serikat mendominasi dengan banyaknya jumlah aliansi di kawasan ini. Seiring menguatnya China di bidang ekonomi, AS merasa dominasi atas Kawasan Asia berkurang. Perubahan terus terjadi ketika negara-negara di Kawasan Asia-Pasifik termasuk negara sekutu AS meningkatkan kerja sama dengan China.

Asia-Pasifik dianggap penting karena lebih dari 50\% populasi dunia berada di kawasan ini. USPACOM menyatakan bahwa beberapa diantaranya merupakan negara dengan kekuatan militer besar dunia, lima negara memiliki perjanjian keamanan dan merupakan aliansi AS. Kelima negara tersebut adalah Jepang, Korea Selatan, Australia, Thailand, dan Filipina (USPACOM). Pentingnya kawasan ini juga dikarenakan adanya dua dari tiga negara dengan ekonomi terbesar di dunia, yaitu China di urutan kedua dan Jepang di urutan ketiga (Bergmann, 2014). Selain itu, Asia-Pasifik termasuk kawasan dengan negara yang mayoritas berpenduduk muslim, serta demokrasi terbesar.

Pertumbuhan ekonomi China meningkat dengan pesat beberapa tahun terakhir. Berdasarkan dokumen 2011 Report to Congress of the US-China Economic and Security Review Commission, China merupakan negara industri terbesar di dunia. Tingkat industri China dapat melampaui AS terutama di bidang manufaktur seperti mobil, ponsel, maupun komputer (U.S. Government, 2011: 1). Terlebih lagi, perusahaan besar AS mempercayakan proses pembuatan komponen produk di China, sehingga memperkuat China sebagai negara Industri terbesar di dunia. Dengan industri terbesar di dunia, perekonomian China terus naik hingga 9\% di tahun 2011 sehingga membuat China menjadi negara dengan ekonomi terbesar kedua di dunia setelah Amerika Serikat (U.S. Government, 2011: 1-2).

Meningkatnya perekonomian China memberikan tantangan tersendiri bagi Amerika Serikat. Kerja sama di bidang perekonomian antara Amerika Serikat dan China terutama di kegiatan ekspor dan impor mengalami peningkatan. Tren tersebut sebenarnya telah terjadi sekitar tahun 2002. Pada saat itu, total ekspor China ke Amerika Serikat lebih besar yaitu sejumlah $\$ 125$ miliar, daripada total ekspor Amerika Serikat ke China yang hanya sejumlah \$19 miliar. Salah satu alasan jumlah ekspor China ke Amerika Serikat lebih besar adalah masyarakat AS lebih konsumtif daripada masyarakat China (Kementrian Luar Negeri Indonesia, 2014). Masyarakat China yang dibayar rendah tidak mampu membeli barang produksi AS yang berharga tinggi. Pada intinya adalah daya beli masyarakat China rendah sehingga permintaan terhadap barang produksi AS menurun, kemudian berdampak pada jumlah ekspor dan impor di kedua negara. Faktor lain yang menyebabkan total ekspor China ke AS lebih besar adalah pertukaran nilai mata uang. Pemerintah China menerapkan kurs tetap yang membuat nilai mata uang Yuan China lebih rendah terhadap Dollar Amerika. Rendahnya mata uang yang ditetapkan pemerintah China membuat harga barang produksi China lebih murah dibadingkan harga barang produksi AS yang masuk ke 
China (Kementrian Luar Negeri Indonesia, 2014).

Dalam kebijakan China's Peaceful Development atau sebutan menurut Amerika Serikat adalah 'China Rise', tidak dapat dipungkiri bahwa saat ini China mengalami peningkatan yang signifikan, serta mampu mempengaruhi negara-negara di Kawasan Asia-Pasifik untuk bekerja sama di segala bidang. Dari segi jumlah sumber daya manusia, China menempati urutan pertama dunia sebagai negara dengan total 1.393.783.836 jiwa, yaitu negara dengan jumlah populasi tertinggi. China menyumbang 19,24\% dari total populasi dunia (Worldmeters, 2014). Jumlah tersebut menempatkan China sebagai pemilik sumber daya manusia terbanyak di dunia. Hal ini menjadikan China memiliki man power dalam hal kapabilitas nasional. Dengan jumlah penduduk yang tinggi, memiliki jumlah tentara untuk melindungi masyarakat menjadi hal yang penting.

Secara GDP, China mengalami pertumbuhan pesat terhitung sejak tahun 2011 hingga tahun 2015. Tahun 2013, total GDP China mencapai dua digit, yaitu berada di angka US $\$ 13,37$ triliun. Pertumbuhan GDP sekitar 7,5\%. Tahun 2011 menuju 2012 lalu, di tengah krisis keuangan gobal, China masih mampu menaikkan GDP dari US $\$ 4,2$ miliar menjadi US $\$ 8,3$ miliar. Kenaikan tersebut sekaligus menjadikan China sebagai peringkat dua dunia dalam pertumbuhan ekonomi.

Anggaran resmi militer China untuk tahun 2010 adalah $\$ 8,12$ miliar, namun Pentagon mengatakan China menghabiskan lebih dari jumlah tersebut (U.S. Government, 2011: 2). Upaya modernisasi angkatan laut China diiringi dengan perubahan strategi. Menurut Laksamana Zhang Huachen, wakil Komandan Angkatan Laut Timur menyatakan bahwa strategi pertahanan China berubah dari pertahanan pantai menjadi pertahanan laut (Wong, 2010). Hal ini sejalan dengan perluasan kepentingan ekonomi China sehingga angkatan laut diorientasikan untuk melindungi jalur transportasi negara dan keamanan laut jalur utama. Untuk mencapai hal ini, Angkatan Laut China perlu mengembangkan sistem pertahanan yang lebih besar dan dengan kemampuan yang lebih komprehensif (Wong, 2010).

Berdasarkan penjelasan di atas, dapat disimpulkan bahwa China mengalami peningkatan di bidang ekonomi dan militer. Hal yang paling terlihat adalah China mampu menggeser posisi Jepang yang dulunya berada di peringkat dua dengan pertumbuhan ekonomi terbesar di Asia. Dalam hal pemenuhan kebutuhan negara, dengan meningkatnya ekonomi, China mampu mengembangkan militernya dengan menambah jumlah personel dan armada baik matra darat, laut, maupun udara.

Military expenditure merupakan bagian dari aggregate power karena dapat melihat seberapa besar alokasi pendapatan negara untuk keperluan militer. Meski tujuan dari peningkatan China adalah bersifat defensif, tetapi pengeluaran belanja militer di masa damai kurun waktu 2011-2014 pada kenyataannya telah menimbulkan keresahan bagi AS.

\section{Gambar 2: Anggaran Belanja Militer 2014}

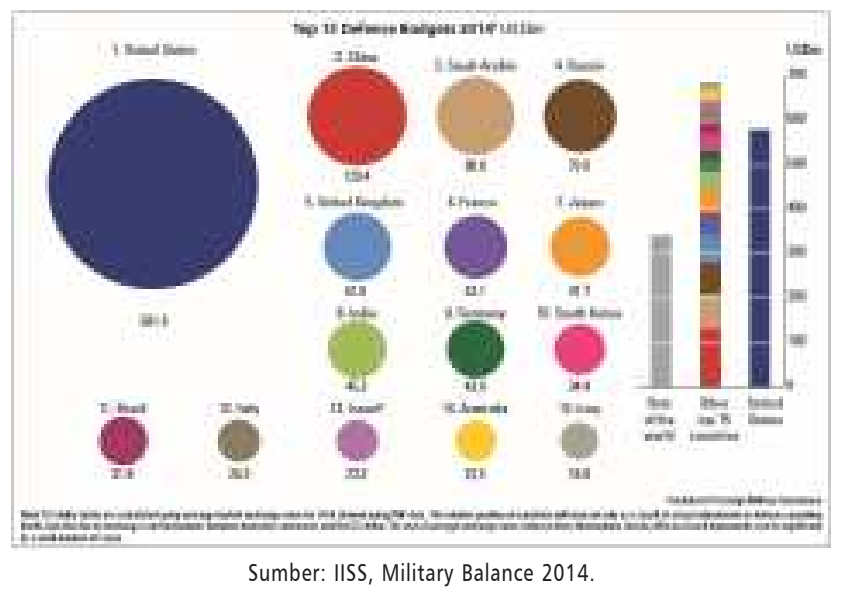

Dari gambar di atas, terlihat bahwa di antara negaranegara di Kawasan Asia-Pasifik, China merupakan negara dengan anggaran militer terbesar. Namun, apabila melihat hadirnya AS di kawasan, maka China harus turun satu peringkat di bawah AS. AS membelanjakan dana pertahanannya di tahun 2013 sebesar US $\$ 1.747$ miliar, diikuti China dengan total belanja militer US $\$ 188$ miliar (SIPRI, 2014).

Batas geografis suatu negara sangat mempengaruhi besar kecilnya ancaman yang ada. Semakin dekat suatu negara yang memberikan ancaman, semakin besar ancaman yang di terima. Jika dikaitkan dalam tulisan ini, China dan Amerika Serikat memang tidak berbatasan darat langsung dan dipisahkan dengan Samudera Pasifik. Namun, posisi Pantai Timur China yang mengarah langsung ke Pantai Barat Amerika Serikat memberikan 
tantangan tersendiri. Kondisi geografis kedua negara yang saling berhadapan memperbesar peluang adanya ancaman. Didukung dengan kemampuan militer yang hingga saat ini terus meningkat, tidak menutup kemungkinan China mampu memberikan ancaman bagi AS. Berdasarkan laporan Amerika Serikat, daya jangkau peralatan militer China sudah mampu mencapai wilayah perairan Amerika Serikat. Selain memiliki militer yang mampu menjangkau wilayah AS, China juga memiliki kemampuan untuk menangkal dari serangan armada negara lain yang disebut dengan A2/AD.

Tidak hanya bagi dirinya sendiri, AS juga mengantisipasi China untuk memberikan ancaman bagi negara aliansinya di Kawasan Asia-Pasifik. Jepang, Korea Selatan, Australia, Thailand, dan Filipina merupakan lima negara aliansi Amerika Serikat sesuai dengan yang disebutkan pada halaman resmi USPACOM. Jika melihat pada negaranegara aliansi AS, Jepang, dan Korea Selatan berada pada jarak terdekat dengan China. Antara China-Jepang dan China-Korea Selatan tidak jarang terjadi gesekan kepentingan baik terkait wilayah maupun saling unjuk kekuatan militer. Sedangkan Thailand dan Filipina, walaupun tidak sedekat Jepang dan Korea Selatan, namun hingga saat ini masih diributkan dengan China terkait sengketa perbatasan di wilayah Laut China Selatan.

Dari kondisi di atas, China tidak hanya memberikan tantangan bagi Amerika Serikat namun juga negara aliansinya. Berdasarkan pernyataan Joe Biden yang merupakan Wakil Presiden AS menyatakan bahwa AS ikut menjaga keamanan negara aliansi di Kawasan Asia-Pasifik dengan memperkuat hubungan terutama militer dan ekonomi melalui Trans-Pacific Partnership (TPP) (The White House - Office of The Vice President, 2013).

Jumlah tentara China yang aktif hingga saat ini sebesar 2,3 juta tentara. Angka tersebut menempati urutan pertama di dunia, dan menyusul di bawahnya Amerika Serikat sebanyak 1,5 juta tentara (China Today, 2014). Selain jumlah tentara aktif, China juga memiliki tentara cadangan dengan jumlah besar, yaitu sekitar 375 juta tentara yang berdasarkan pada jumlah penduduk antara umur 15-49 tahun (Military Education, 2015). Hal tersebut meningkatkan kesadaran AS bahwa jumlah populasi China menjadi ancaman dan memberikan pengaruh untuk menghadapi persaingan kualitas sumber daya manusia.

Angkatan darat China (PLA Ground Force) mempunyai pasukan regular terdiri 1,7 juta personil, dengan 800.000 personil tambahan dan cadangan (Military Education, 2015). Hal ini menunjukkan bahwa China memiliki tentara aktif terbesar di dunia, dan kedua terbesar dari segi personil tentara. Angkatan darat China ini telah dan terus mengalami pembaharuan besar yang cepat untuk menghadapi perang. Dalam hal ini pasukan garis depan, pasukan khusus diberikan prioritas dalam pengalokasian senjata modern yang lebih baru. PLA juga telah meningkatkan kemampuan medan pertempuran melalui C4ISR, dengan pengenalan komunikasi satelit, jaringan wireless, dan radio digital (China Today, 2014).

Angkatan udara China (PLA Air Force) memiliki 330.000 personil disertai 2.500 pesawat udara dimana 1.617 pesawat adalah pesawat udara untuk menyerang, dan 400 diantaranya adalah pesawat terbaru. Hal ini membuat angkatan udara China terbesar ketiga setelah AS dan Rusia sekaligus mengindikasikan angkatan udara terbesar di Asia. Bahkan, angkatan udara China juga dilengkapi dengan akuisisi pesawat $\mathrm{Su}-30$ dan F-10 yang dilengkapi amunisi tempur seperti satelit dan rudal jelajah untuk melakukan serangan dari udara ke udara (China Today, 2014).

Menurut China's Defense White Paper 2010, angkatan laut China telah meningkatkan dan mengoptimalkan persenjataan dan peralatan angkatan lautnya. Upaya yang dilakukan adalah dengan membangun tipe baru kapal selam, kapal perusak, frigat, dan pesawat. Kapabilitas persenjataan dibentuk dengan sistem peralatan generasi kedua sebagai inti dan generasi ketiga sebagai penyokong alutsista yang sudah ada sebelumnya (U.S. Government, 2011: 162-164). Berdasarkan Annual Report to Congress tahun 2013, perkembangan kekuatan kapal selam China memiliki anti kapal di bawah air, anti kapal selam, serta memiliki kemampuan serangan balik nuklir (Office of the Secretary of Defense, 2013: 5-7). Hingga tahun 2012, angkatan laut China memiliki 72 kapal penyerang yang terdiri dari kapal selam sejumlah 58, kapal selam menengah sejumlah 50 unit, serta rudal untuk patroli sepanjang Pantai Timur China sebanyak 41 buah. Pembaharuan teknologi sesuai dengan kebijakan China yang mengharuskan adanya modernisasi, saat ini China sedang 
membangun dan menguji peningkatan tipe kapal selam kelas JIN (Type 094) bertenaga nuklir dan kapal selam rudal balistik dengan kelas Shang (Type 093) (Office of the Secretary of Defense, 2013: 5-7).

Strategi yang dijalankan oleh China saat ini adalah blue water capability (Office of the Secretary of Defense, 2013: 38-39). Strategi tersebut diwujudkan dalam tiga tahap, pertama memperlihatkan kekuatan laut dan keberadaan pasukan di sekitar Pasifik Barat dan Samudera Hindia. Kedua, adalah dengan menempatkan kekuatan laut dalam jangka waktu yang lama, serta ketiga adalah penugasan seluruh wilayah Asia. Saat ini, PLA Navy sedang mengarah ke tahap dua, dengan mempersiapkan kapabilitas yang mendukung penempatan masukan dalam waktu lama, salah satunya adalah pengembangan kapal induk (Pike, 2014). China masih dapat dikategorikan sebagai kekuatan berkembang. Didukung dengan pertumbuhan ekonomi, maka antara ekonomi dan militer akan tumbuh secara beriringan. Peningkatan-peningkatan kapabilitas China merupakan sebuah bentuk modernisasi yang menjadi fokus kebijakan pertahanan. Dari sisi anggaran belanja, pembaruan alutsista, serta peningkatan kualitas tentara masih terus dilakukan.

Pernyataan yang pernah dipaparkan oleh Hu Jintao 'The navy should be strengthened and modernized. The navy should be prepared at any time to military struggle' (Wolfe, 2007) yang mana pernyataan ini merefleksikan keinginan China untuk memodernisasi angkatan pertahanannya, khususnya angkatan laut yang dipersiapkan untuk pertarungan militer. Hal ini kemudian berdampak kepada peningkatan kapabilitas militer China yang signifikan.

Jumlah angkatan bersenjata tidak semuanya dapat mewakili kekuatan suatu negara dalam melakukan penyebaran pasukan. Hal tersebut disebabkan jumlah angkatan bersenjata yang dimiliki oleh suatu negara merupakan hasil keseluruhan anggota aktif, administratif, dan pemeliharaan. Dengan banyaknya jumlah pasukan, suatu negara mampu memproyeksikan kekuatannya melalui pendaratan pasukan-pasukan militer untuk melancarkan kepentingannya.

Peningkatan ekonomi yang menjadi nomor dua terbesar di dunia setelah Amerika Serikat, diikuti dengan peningkatan kekuatan militer menjadikan China sebagai negara emerging power terbesar di Kawasan Asia-Pasifik. Peningkatan tersebut dianggap wajar karena dalam strategi pertahanan China bersifat defensif. Hal tersebut seperti yang tertulis di halaman buku putih pertahanan (defense white paper), China menyatakan kebijakan pertahanannya bersifat active defensive (Information Office of the State Council, 2013). Kebijakan tersebut sekaligus menunjukkan bahwa peningkatan militer China merupakan hal yang wajar dilakukan. Walaupun, perkembangan militer China saat ini sedang mengarah menjadi offensive dengan kemampuan Anti-Access/Area Denial.

Kemampuan Anti-Access/Area Denial juga menyesuaikan dengan kondisi geografis China yang merupakan negara terluas di Asia. China memiliki perbatasan daratan maupun lautan dengan negara lain. Garis Pantai Timur China berbatasan langsung dengan Korea Utara, Korea Selatan, dan Jepang. Lebih jauh lagi kearah timur, China berhadapan dengan Pantai Barat Amerika Serikat. Persepsi bahwa China menimbulkan ancaman bagi negara tetangga terutama negara sekutu AS sebenarnya beralasan, karena kebanyakan dari mereka memiliki batas langsung dan jarak yang relatif dekat dengan China. Faktor kedekatan batas wilayah tidak hanya berlaku antara China dan negara tetangganya di Kawasan Asia-Pasifik tetapi juga di semua negara.

China diharuskan segera mengembangkan kemampuan militer berteknologi tinggi. Artinya, pengembangan strategi nasional akan ditekankan pada keamanan wilayah laut dan pantai, serta membangun kekuatan maritim. Hal tersebut menunjukkan bahwa China tidak berhenti untuk melakukan modernisasi di seluruh sektor, yaitu darat, laut, dan udara (Hartnett, 2013: 9). Angkatan bersenjata China atau yang dikenal dengan People's Liberation Army (PLA), terdiri dari tiga elemen, yaitu angkatan darat (PLA Ground Force), angkatan laut (PLA Navy), dan angkatan udara (PLA Air Force) serta Second Artilery Force (Hartnett, 2013: 9).

\section{IMPLEMENTASI STRATEGI REBALANCING}

United States Fiscal Year 2013 yang diputuskan mengarah pada peningkatan perjanjian antara pemerintah AS terhadap lima aliansinya di Kawasan Asia-Pasifik. Perjanjian tersebut menegaskan bahwa pembentukan postur pertahanan di kawasan terus ditingkatkan seiring dengan 
penetapan upaya rebalancing. Keberadaan aliansi AS di Kawasan Asia-Pasifik telah berlangsung sejak lama, dan pakta aliansi tersebut terus diperbarui hingga saat ini. Namun, tulisan ini hanya akan memfokuskan pada tiga (3) aliansi besar AS, yaitu Jepang, Korea Selatan, dan Australia.

Peningkatan aliansi antara AS dan Jepang kembali dilakukan pada tahun 2010 berdasarkan 2010 National Defense Program Guidelines, yang memfokuskan penguatan kerja sama aliansi dengan melibatkan aliansi yang lain di Kawasan Asia-Pasifik. India dan Australia masuk menjadi negara yang mendukung kerja sama aliansi, sebagai negara dengan kekuatan maritim yang disebut dengan 'dynamic defense'. Artinya, AS, India, dan Australia melakukan kerja sama dalam hal menangkal Korea Utara, serta melindungi kedaulatan maritim Jepang dengan melakukan operasi di sekitar Okinawa (U.S. Government, 2012: 21-23).

Ketika AS memfokuskan kebijakan di Kawasan AsiaPasifik di akhir tahun 2011, ikatan kerja sama aliansi AS dan Jepang kembali diperkuat. Pada April 2012 terbentuk U.S-Japan Security Consultative Committee (SCC), yang menyetujui peningkatan kapabilitas di Guam dan negara Commonwealth (Negara Mikronesia) sebagai tempat pelatihan, proteksi terhadap jalur pipa, serta peningkatan infrastruktur. Berdasarkan artikel yang dirilis oleh White House tentang U.S.Japan Joint Statement tahun 2014, antara AS dan Jepang melakukan penguatan terkait peningkatan tensi di Laut China Timur dan Laut China Selatan, dengan mendeklarasikan Air Defense Identification Zone in the East China Sea. Dengan adanya deklarasi tersebut, Jepang mendukung penempatan dan penambahan pasukan di Guam dan Okinawa (U.S. Government, 2012: 21).

Seiring dengan diberlakukannya Fiscal year 2013, kerja sama pertahanan antara pemerintah Korea Selatan dengan AS adalah meningkatkan kapabilitas elemen pertahanan, seperti komando, kontrol pasukan, komunikasi, komputer, intelijen, transportasi, cyber security, serta melakukan sistem kontrol yang menangkal apabila terjadi peningkatan senjata misil. Dalam hal peningkatan aliansi terkait konstelasi ancaman terutama yang berhubungan dengan China, Korea Selatan yang bersengketa dengan Korea Utara merasa perlu melakukan peningkatan porsi aliansi dengan AS. Hal tersebut dikarenakan China ikut mendukung upaya penekanan denuklirisasi terhadap Korea Utara, tetapi sekaligus sebagai penyedia suplai makanan dan bahan bakar ke Korea Utara.

Mengacu pada perubahan arah fokus AS ke Kawasan Asia-Pasifik, pada tahun 2012 setelah kunjungan Presiden Obama di tahun 2011, pangkalan Amerika Serikat yang berada di sekitar Australia diperbarui. Sekitar 200 marinir Amerika Serikat ditambahkan dan disambut baik oleh Perdana Menteri Australia pada saat itu, Julia Gillard. Berdasarkan peningkatan perjanjian, tahun 2017 AS akan menambah pasukan sebanyak 2.500 pasukannya, yang akan dikonsentrasikan sekitar Pulau Cocos (Minister for Defence, 2011).

Strategi rebalancing ini juga mengacu kepada upaya AS untuk mengoreksi dugaan pengabaian Kawasan Asia-Pasifik oleh pemerintahan George W. Bush. Sebelum Presiden Obama menjabat, banyak pemimpin Asia Tenggara di wilayah ini merasa mereka telah diabaikan oleh AS. Adanya kebijakan War on Terror dan komitmen militer AS di Irak dan Afghanistan telah membuat strategi rebalancing dimaksudkan untuk menyeimbangkan kembali perhatian ke kawasan ini. Istilah ini juga dipilih untuk mencegah adanya anggapan bahwa AS meninggalkan perhatiannya di kawasan lain dan beralih ke Asia-Pasifik.

Strategi rebalancing juga mencerminkan kebutuhan untuk mengartikulasikan prioritas global Amerika Serikat setelah penarikan pasukan dari Irak dan Afghanistan, yang membebaskan sumber daya diplomatik dari militer AS ke Timur Tengah selama sepuluh tahun terakhir. Pengurangan dalam pengeluaran dan anggaran militer federal AS juga menyerukan pernyataan yang jelas tentang prioritas strategis AS untuk mengalokasikan sumber daya yang terbatas. Untuk militer AS, hal ini datang dalam bentuk panduan pertahanan strategis Januari 2012 yang ditandatangani oleh Presiden Barack Obama, yang menyatakan akan menyeimbangkan kebutuhan menuju wilayah Asia-Pasifik (Department of Defense of United States of America, 2012: 4-5).

\section{KESIMPULAN}

Perilaku AS yang melakukan strategi balancing melalui kebijakan rebalancing merupakan bentuk sekaligus konfirmasi atas adanya rasa tidak aman terhadap 
peningkatan kapabilitas yang sedang dialami oleh China dalam beberapa dasawarsa terakhir. Rasa tidak aman ini tercermin dalam operasionalisasi teori Balance of Threat yang dapat dikatakan sebagai ancaman kekuatan oleh China. Meskipun China saat ini menjadi The New Emerging Power terutama di Kawasan Asia-Pasifik, namun tidak dapat dikatakan sepenuhnya bahwa dominasi kekuatan dunia telah pindah ke tangan China. Pada kenyataannya, China masih jauh dalam upaya mempersempit jarak kekuatannya dengan AS. Dalam hal ini dibutuhkan proses yang panjang dan membutuhkan kesiapan serta kemandirian dari segala aspek sumber daya.

Strategi balancing yang dilakukan oleh AS melalui penguatan aliansi militer merupakan strategi yang sesuai untuk mempersempit ruang gerak China untuk mendominasi Kawasan Asia-Pasifik. Hal tersebut dikarenakan penggunaan strategi balancing akan menguntungkan AS karena tetap dapat mempertahankan dominasinya sebagai negara terkuat di antara negara-negara aliansinya yang berada di Kawasan Asia-Pasifik.

Hal yang dapat menjadikan China menjadi ancaman dapat dibuktikan melalui perhitungan dan perimbangan kekuatan yang sesungguhnya, yaitu aggregate power, geographical proximity, offensive power, dan aggressive intentions. Pembuktian tersebut diproyeksikan dengan adanya penguatan aliansi militer AS di Kawasan Asia-Pasifik melalui upaya rebalancing, yang salah satunya adalah strength ening alliance. Upaya tersebut memberikan AS pilihan strategi yaitu balancing dan/atau bandwagoning. Respon AS atas adanya peningkatan atau China Rise merujuk pada upaya strategi balancing dengan dibentuknya aliansi militer AS dalam rangka menghadapi dinamika di kawasan atas pertimbangan strong states ws weak states, availability of alliance, serta peace and war condition sesuai dengan teori Balance of Threat.

Meskipun China cukup diperhitungkan, namun jika disejajarkan dengan AS, maka akan terlihat perbedaan bentuk interaksi antara AS sebagai strong states dengan China sebagai middle-weak states. Selain itu, ability of alliance dapat dilihat pada jumlah negara aliansi AS, serta kedekatan antar-negara aliansi yang cukup berdekatan dan dapat menjangkau dalam waktu cepat. Kedua pertimbangan tersebut sekaligus menguatkan pilihan AS untuk melakukan re-balancing dalam menghadapi potensi ancaman yang muncul. Pertimbangan peace condition justru turut menjadi pendukung untuk lebih melakukan penguatan aliansi, dibandingkan melakukan aksi yang agresif atas munculnya potensi ancaman dari China.

\section{CATATAN BELAKANG}

1 USPACOM merupakan salah satu dari enam Komando Satuan Tempur yang secara geografis bertanggung jawab di Kawasan Asia-Pasifik. USPACOM bekerja sama dengan aliansi dan pihak lain di Kawasan Asia-Pasifik untuk menjaga dan mempertahankan wilayah Amerika Serikat termasuk warga dan kepentingan nasionalnya. (http://www.pacom.mil/ AboutUSPACOM.aspx.diakses tanggal 17 Desember 2016).

\section{REFERENSI}

JURNAL

Dwivedi, Sangit S. 2012. Alliances in International Relations Theory. International Journal of Social \& Interdisciplinary Research Vol. 1. Issue 8, Agustus 2012: 224-237.

Walt, Stephen M. 2007. Alliance Formation and the Balance of World Power. International Security, Vol. 9, No. 4, 2007: 3-43.

\section{BUKU}

Hartnett, Daniel M. 2013. China's 2012 Defense White Paper: Panel Discussion Report. Alexandria, VA: Mark Center Drive. CSIS. 2012. U.S Force Posture Strategy in the Asia-Pacific Region: an Independent Assessment. Washington DC: Center for Strategic and International Studies.

Nathan, Andrew J., dan Robert S. Ross. 1997. The Great Wall and The Empty Fortress: China's Search for Securty. New York: W. W. Norton.

SIPRI. 2014. 'Sipri'. Trends in World Military Expenditure 2013. (Daring), (http://books.sipri.org/files/FS/SIPRIFS1404.pdf. diakses pada 8 Maret 2016).

Sunardi, RM. 2004. Geopolitik dan Geostrategi Indonesia: Pembinaan Ketahanan Nasional. Jakarta: PT Kuarternita Adidharma.

Swaine, Michael D. t.thn. Chinese Leadership and Elite Responses to the U.S. Pacific Pivot. China Leadership Monitor, No. 38: 4-5.

Walt, Stephen M. 1987. The Origins of Alliances. Ithaca: Cornell University Press.

Waltz, Kenneth. 1979. Theory of International Politic. New York: Random House.

\section{ARTIKEL}

Bijan, Zheng. 2005. China's 'Peaceful Rise' to Great-Power Status. (Daring), (http://www.foreignaffairs.com/articles/61015/zhengbijian/chinas-peaceful-rise-to-great-power-status. diakses pada 23 Desember 2016).

Clinton, Hillary. 2011. America's Pacific Century. (Daring), (http:// www.foreignpolicy.com/articles/2011/10/11/ 
americas_pacific_century. diakses pada 21 Februari 2016).

Military Education. 2015. The Growth of The Chinese Military. (Daring), (http://www.militaryeducation.org/chinese-militarygrowth/. diakses pada 8 Januari 2016).

Pike, John. 2014. WU-14 Dong Feng-21D (DF-21D)/CSS-5 Mod 5 Anti-Ship. (Daring), (http://www.globalsecurity.org/wmd/world/ china/df-21d.htm. diakses pada 14 Januari 2016).

World Bank. 2013. GDP, PPP (Current International \$). (Daring), (http://data.worldbank.org/indicator/NY.GDP.MKTP.PP.CD/ countries/order\%3Dwbapi_data_value_2013\%20wbapi_data_value\%20wbapi_data_value-last?order=wbapi_data_value_2012\%20wbapi_data_value\%20wbapi_data_value-

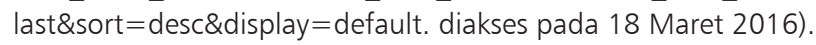

Worldmeters. July 2014. China Population (Live). (Daring), (http:// www.worldometers.info/world-population/china-population/. diakses pada 8 Januari 2016).

\section{SUMBER RESMI KENEGARAAN}

Australian Government. 1951. 'ANZUS Treaty'. (Daring), (http:// www.dfat.gov.au/geo/new_ze aland/anzus.pdf. diakses pada 21 Februari 2016).

Congressional Research Service. t.thn. Pivot to the Pacific? The Obama Administration's 'Rabalancing' Toward Asia. CRS Report for Congress, March 28, 2012.

Department of Defense of United States of America. 2012. Sustaining U.S. Global Leadership: Priorities for 21 st Century Defense. Washington, D.C: Department of Defense.

Department of External Affairs, Canberra. 1997. Security Treaty Between Australia, New Zealand and The United States of America (ANZUS). Canberra: Australian Government Publishing Service.

Information Office of the State Council of The People's Republic of China. 6 September 2011. China Peaceful Development. (Daring), (http://www.china.org.cn/government/whitepaper/ node_7126562.htm. diakses pada 23 Februari 2016).

Information Office of the State Council. 2013. The Diversified Employment of China's Armed Forces. Beijing: Information Office of the State Council.

Information Office of the States Council. 2013. The Diversified Employment of China's Armed Forces. Beijing: China's Government.

Kementrian Luar Negeri. 2014. Informasi Dasar RRT. Kemlu. (Daring), (http://www.kemlu.go.id/beijing/Documents/ Informasi\%20Dasar\%20RRT.pdf diakses pada 16 Maret 2016).

Minister for Defence. 2011. The Asia-Pacific Century and The Australias-Unted States Allaince. (Daring), (http:// www.minister.defence.gov.au/2011/07/27/minister-for-defencethe-asia-pacific-century-and-the-australia-united-states-alliance/ diakses pada 18 Februari 2016).

Office of Secretary of Defense. 2011. Annual Report to Congress: Military and Security Developments Involving People's Republic of China. Washington DC: Department of Defense.

Office of the Secretary of Defense. 2013. Annual Report to Congress: Military and Security Developments Involving the People's Republic of China. Washington DC: Department of Defense.
President Barack Obama. 2011. Fact Sheet: Fiscal Year 2014 Federal Budget and the Asia-Pacific. (Daring), (http:// www.whitehouse.gov/sites/default/files/docs/ asia_pacific_rebalance_factsheet_20130412.pdf diakses pada 21 Februari 2015).

State Council Information Office. Desember 2005. China's Peaceful Deveopment Road. (Daring), (http://en. people.cn/200512/22/ eng20051222_230059.html diakses pada 23 Februari 2016).

U.S. Department of Defense. Januari 2013. Sustaining US Global Leadership: Priorities for 21st Century Defense. (Daring), (http:// www.defense.gov/news/defense_strategic_guidance.pdf diakses pada 1 September 2013).

USPACOM. t.thn. Headquarters, United States Pacific Command. (Daring), (http://www.pacom.mil/AboutUSPACOM.aspx diakses pada 18 December 2015).

The White House - Office of the Press Secretary. 17 November 2011. Remarks By President Obama to the Australian Parliament. (Daring), (http://www.whitehouse.gov/the-press-office/ 2011/11/17/remarks-president-obama-australian-parliament diakses pada 14 Februari 2015).

The White House - Office of The Vice President. 2013. Remarks by Vice President Joe Biden on Asia-Pacific Policy. (Daring), (http:// www.whitehouse.gov/the-press-office/2013/07/19/remarksvice-president-joe-biden-asia-pacific-policy diakses pada 8 Mei 2015).

U.S. Government. 2014. 2014 Report to Congress of US-China Economic and Security Review Comission. Washington: U.S. Government Printing Office.

U.S. Government. 2012. Report to Congress of The U.S-CHina Economic and Security Review Comission. Washington, DC: U.S. Government Printing Office.

U.S. Government. 2011. Report to Congress of the US-China Economic and Security Review Comission. Washington: U.S. Government Printing Office.

\section{BERITA}

China Today. 2014. China Military and Armed Forces (People's Liberation Army, PLA). (Daring), (http://www.chinatoday.com/ arm/china-military.htm diakses pada 8 Januari 2016).

Liu, Wen. 22 Maret 2013. From Pivot to Rebalance: The Weight of Words in U.S. Asia Policy. (Daring), (http://contextchina.com/ 2013/03/from-pivot-to-rebalance-the-weight-of-words-in-u-sasia-policy/ diakses pada 21 Februari 2016).

Reis, J.Arthur. 24 Januari 2014. China's Dual Response to the US 'Pivot'. Asia Times, (Daring), (http://www.atimes.com/atimes/ China/CHIN-01-240114.html diakses pada 14 Oktober 2016).

Wolfe, Adam. Januari 2007. China Puts the Focus on The Navy. Asia Times, (Daring), (http://www.atimes.com/atimes/China/ IA10Ad01.htmldiakses pada 12 Januari 2016).

Wong, Edward. April 2010. Chinese Military Seeks to Extend Its Naval power. New York Times, (Daring), (http:// www.nytimes.com/2010/04/24/world/asia/24navy.html?_r=0 diakses pada 17 Februari 2016 